\title{
PERSPEKTIF MODERNISASI MENUJU TERWUJUDNYA KELUARGA SEJAHTERA
}

\author{
Rosita Carolina*
}

Surel:

\begin{abstract}
The role of families in the establishment of science and technology is divided into two, namely as the perpetrators of change and change agents. As perpetrators of change, families must master the science and technology (IPTEK) and try to have a superior personality such as never give up, creative, disciplined, responsible, trustworthy and become the main and main educator in the family. The next benefit is that families are able to use information about science and technology and how to apply it in the life of their family members, so as to improve their lives independently to a professional family. This participation should not always be in the form of work, in the sense of devoting themselves to institutions outside the household or the like, but more than that is working in the sense of carrying out its duties as a giver of life in the household. The family in its capacity as a whole personality developer is thorough, need to perform and prevent the negative impact of modernization of science and technology in the global dimension. For the realization of this role, the family must be able to prepare family members can withstand the mental shocks due to the influence of global science and technology. This is the subject of further trends, the meaning of modernization and its influence on the family as one of the center of attention today.
\end{abstract}

Keywords; Moderenisasi and family roles

\section{PENDAHULUAN}

adalah
kemerdekaan $\quad \begin{aligned} & \text { mengisi } \\ & \text { melalui }\end{aligned}$ prestasi mereka dalam pembangunan yang sedang digiatkan di semua bidang kehidupan. Dalam pembangunan yang beragam dan terus meluas merupakan tantangan bagi keluar ${ }^{1}$ ga atas peran yang harus dipegangnya dalam menempatkan cita-cita bangsa. Implikasinya Keluarga harus pandai membagi diri dan mengalokasikan waktu agar tercapai kemantapan, keselarasan,

*Dra. Rosita Carolina, M.Pd. Dosen Jurusan PKK FT UNIMED dan keserasian serta keseimbangan pada hal kontribusi dalam keluarga umumnya sangat signifikan. Kemitra dimaksud disadari oleh adanya kebersamaan tanggung jawab, harkat dan martabat, sementara kemitra yang sudah ada hendaknya dijaga dan dibina juga dikembangkan sesuai dengan proses arah, makna dan pengaruh pembangunan nasional dan perubahan global. Perubahan terjadi dipengaruhi kecenderungan makna proses yang terjadi dalam mewujudkan citra keluarga.

Komitmen ini, secara bersama akan dicapai sesuai dengan batas kemampuan sebagaimana diuraikan melalui amanat GBHN, yang isinya 
antara lain menyatakan "Peranan keluarga dalam pembangunan diupayakan berkembang selaras dan serasi dengan perkembangan tanggung jawab dan perenannya dalam mewujudkan dan mengembangkan keluarga sehat, sejahtera, dan bahagia, termasuk pengembangan generasi muda seutuhnya". Dari amanat ini dapat diartikan bahwa dalam perkembangan masyarakat Iptek di Indonesia, sebagai titik awal pengemban budaya juga mempunyai peran sentral dalam menciptakan masyarakat Iptek yang responsif terhadap era IPTEK yang sering dikategorikan sebagai era modernisasi.

Modernisasi global dalam
perkembangan IPTEK dengan
konsultasi sebagaimana diuraikan di
atas memiliki dampak positif dan
negatif. Dampak yang bersifat
negatif, terjadi pada keluarga yang
belum memiliki kepribadian yang
mantap dan lengkap. Beberapa
dampak yang ditimbulkan oleh
proses modernisasi global itu adalah
sifat egoisme, materialisme, ingin
menempuh jalan pintas, cepat meniru
yang berbau modern, menurunnya
nilai budaya luhur, ingin cepat kaya
melalui cara yang melanggar norma
hukum, dan mudah stress serta
frustasi.

Dengan demikian, tantangan dalam keluarga kini dan masa mendatang adalah terletak pada kemampuan untuk mengembangkan individu secara utuh dan dengan kapasitas yang lengkap untuk belajar secara berkelanjutan, memberi respon yang kreatif dan mampu memberi penilaian maupun pendapat yang kritis, guna menghadapi corak kehidupan kini dan masa depan yang sangat kompleks, khususnya akibat pengaruh Iptek dan modernisasi dalam dimensi global.

Dalam kapasitasnya sebagai pengembang kepribadian yang utuh menyeluruh, maka dalam keluarga perlu adanya peran mencegah dampak negatif dari modernisasi Iptek dalam dimensi global. Untuk mewujudkan peran ini, orangtua dituntut mampu mempersiapkan anak agar dapat tahan terhadap goncangan mental akibat pengaruh Iptek yang global. Inilah yang menjadi pokok bahasan lebih lanjut yaitu arah kecenderungan, makna modernisai dan pengaruhnya terhadap keluarga sebagai salah satu pusat perhatian.

\section{Keluarga Dalam Harkat dan Martabat di Masyarakat}

Struktur pola dalam kehidupan berkeluarga berubah secara cepatnya sesuai dengan perubahan dan perkembangan Iptek, baik bentuk penampilannya maupun aktivitasnya. Untuk mewujudkan dan menjawab tantangan berkehidupan dalam keluarga perlu mendapat tempat yang seimbang di tengah 
perkembangan Iptek di Indonesia saat ini dan di masa mendatang. Kontribusi untuk merealisasikan semangat dimaksud dalam segenap jajaran sosio-kultural masyarakat, merupakan suatu konsekuensi logis dari hasil pendidikan yang ditekuni selama ini. Pendidikan dan perkembangan sangat penting untuk mengimbangi kemajuan Iptek dalam proses modernisasi, jika hal ini tercapai maka dapat dicegah terjadinya kelambanan kultural.

Keberhasilan ini tampak dari tingkat pendidikan dalam keluarga saat ini sangat mempengaruhi angka partisipasi angkatan kerja keseluruhan. Angka partisipasi ini, merupakan indikator bahwa keinginan keluarga untuk mendapatkan otonomi daerah dalam mewujudkan kemandiriannya cukup besar. Namun dalam mewujudkannya selalu menghadapi kendala budaya yang sudah melekat dan harus membina rumah tangga dengan baik.

Maka timbul pertanyaan, bagaimana pola yang tepat dalam upaya memadupadankan keduanya agar kodrat sebagai ibu dan istri dapat optimal. Dari dalam keluarga yang dididik dasar budi pekerti, nilai-nilai insani yang merupakan harkat untuk hidup bermasyarakat kelak bila anak sebagai anggota keluarga dewasa, akan mendapat tempat yang baik pula. Juga dasar kesehatan fisik, gizi anak, higiene dan kesehatan bagi tumbuh kembanganga anak secara optimal.

Dengan adanya modernisasi global ternyata meningkatkan dinamika gerak hidup yang lebih eksplosif, sehingga kecenderungan kebanyakan orang untuk lebih memperhatikan hasil dari pada proses. Keinginan meraih hasil secepatnya tanpa mau bersusah payah, meski terkadang cara yang ditempuh keliru. Sikap gotong royong makin memudar, dan sikap individualisme makin menonjol. Inilah salah satu dampak negatif dari era modernisasi global. Sebab pada dasarnya teknologi baru telah mengubah pentingnya skala dan lokasi serta memperpanjang kekuatan individu (John Naisbitt dan Patricia, 1990).

Adanya kecenderungan konsep hidup masyarakat yang lebih megarah pada konsumerisme dan individualisme yang tentunya tidak sesuai dengan kepribadian bangsa dan dapat menimbulkan keanekaragaman kehidupan sosial kultural dalam berbagai kelompok lapisan masyarakat saat ini.

\section{Keluarga dan Proses Modernisasi}

Modernisasi memerlukan
kesiapan menerima perubahan
tingkah laku, sikap dan nilai-nilai
baru yang terjadi dalam masyarakat
Iptek. Modernisasi bersifat preventif
dan konstruktif serta tidak bersifat
angan-angan semata, maka melalui


proses modernisasi dapat diproyeksikan kecenderungan yang ada dalam keluarga saat ini terbentuknya budaya Iptek. Sebagaimana telah disinggung diatas bahwa peran keluarga dalam kemajuan Iptek adalah membawa sikap dan tujuan hidup generasi penerus bangsa masa mendatang menuju tercapainya masyarakat adil dan makmur berdasarkan Pancasila. Untuk mencapai tujan tersebut diperlukan kearifan dalam kehidupan berkeluarga yang mempunyai sikap kongruen/serasi dan sesuai. Memperoleh sikap tertentu bukanlah merupakan proses yang mudah namun meminta waktu serta kondisi yang merangsang atau kondusif untuk mewujudkan citra diri yang diinginkan itu. Dengan kata lain perubahan sikap dalam kehidupan berkeluarga merupakan suatu proses modernisasi tidak terjadi begitu saja. Oleh karena itu kepala keluarga diberi kemampuan untuk memiliki unsur-unsur yang menopang tercapainya kemajuan Iptek di Indonesia, baik berdasarkan unsur budaya maupun aspek perkembangan industri. Yang jelas bahwa kebudayaan akibat kemajuan Iptek bisa menjadi pendorong, tetapi juga bisa menjadi penghalang bagi proses modernisasi.

Selanjutnya diperlukan sifatsifat universal seperti cermat, hemat, rajin, tepat waktu dan berani. Sifatsifat ini tentu ada akarnya dalam budaya kita, tinggal bagaimana mengolahnya saja. Dengan singkat memajukan Iptek dalam proses modernisasi bukan hanya bertumpu pada budaya industri yang ada, tetapi juga berfungsi sebagai dinamisator (penggerak) ke arah pengembangan Iptek yang ditopang dengan program melek Iptek.

Dalam era ini yang paling dominan adalah menyangkut ilmu, teknologi, ekonomi dan lingkungan hidup. Akan tetapi tidak berarti bahwa bidang-bidang lain tidak ikut terbawa arus, yang pada akhirnya akan berpengaruh terhadap wawasan dan pola pikir sebagai kelompok masyarakat dan bahkan dapat mempengaruhi pandangan dunia.

Beberapa dampak positif dari modernisasi global di antaranya adalah memperoleh kesempatan untuk memperbaiki kemajuan negara-negara lain, termasuk kelebihan dan kekurangannya serta dampaknya dalam kehidupan masyarakat. Dengan demikian peran keluarga akan berubah suai dengan perkembangan saat ini, namun demikian diakui bahwa semua ini tidak dapat lepas dari dorongan adanya kebutuhan yang bersifat praktis di bawah pengaruh kemampuan para pemikir.

\section{Keluarga Dalam Kemajuan IPTEK}

Keluarga merupakan decade dimana sekelompok orang hidup bersama, mempersiapkan generasi 
bangsa yang akan hidup di dalam rumah tangganya, lalu timbul pertanyaan melalui renungan apakah upaya yang dapat dilakukan para kepala keluarga itu dalam mempersiapkan anak-anak mereka, agar mampu hidup dan menyesuaikan diri pada kemajuan Iptek yang sejak dua dekade terakhir ini bergerak maju begitu pesatnya. Disini semakin jelas bahwa sejak dini pembudayaan Iptek perlu ditanamkan melalui kegiatan bermain anak dirumah, karena Iptek dapat dipandang sebagai suatu konsep produk dan akhirnya sebagai suatu konsep budaya (UNESCO, 1992). Pentingnya upaya ini disebabkan karena membangun budaya Iptek adalah hal yang sulit, tetapi jika berhasil maka merupakan landasan yang paling kuat untuk pengembangan generasi bangsa di masa mendatang.

Untuk mengejar ketertinggalan ini, dituntut peran serta keluarga untuk: 1), mempersiapkan anak-anak sejak dari rumah dengan kualitas Iptek sesuai potensi anak agar mereka mampu mendukung upaya alih teknologi; 2), menata sistem alih teknologi memalui media elektronik sesuai dengan dimensi psikologi anak; 3), mempersiapkan keluarga dan anggotanya menjadi orangtua agar memiliki wawasan tentang kemajuan Iptek. Dalam upaya mencapai ketiga harapan ini, diperlukan tiga aspek yaitu sikap, metode atau proses dan produk.
Ketiga aspek inilah yang mendasari upaya pengembangan Iptek melalui rumah atau dalam keluarga agar anak-anak mampu ; 1) mengaitkan konsep Iptek sederhana kedalam obyek dan proses bermain 2), memahami dampak sederhana yang praktis dari Iptek terhadap lingkungan bermainnya, 3), menyesuaikan kemampuan anak dengan lingkungan rumah dalam dimensi Iptek. Sebagai contoh dituntut kemampuan peran keluarga menjelaskan proses menanak nasi, dari mulai ditanak sampai menjadi nasi yang diap untuk dihidangkan. Dalam mewujudkan contoh ini tentunya dituntut pengetahuan dasar Iptek sederhana, yang dapat diberikan pada keluarga melalui tingkat pendidikan formal yang mereka peroleh.

Untuk anggota keluarga yang tidak tuntas mengenyam pendidikan formal, kepada mereka dilakukan penyuluhan agar sadar Iptek, kemudian dilanjutkan dengan program orientasi teknologi sehingga mereka mampu menghadapi dan memberi bekal persiapan Iptek pada anak-anaknya. Upaya-upaya ini oleh UNESCO (1992) dirumuskan dalam istilah "Science and Technology Literacy" yang didampingi oleh motto Science for All. Perumusan ini merupakan satu langkah lebih maju dalam merefleksikan pentingnya penguasaan, penerapan, dan pengembangan Iptek. Penekanan pentingnya hal ini sajak dari rumah 
atau keluarga tidak berarti terabaikannya fungsi guru, melalui pendidikan formal karena pada pundaknyalah dituntut langsung tanggung jawab melaksanakan peran pembelajaran tersebut.

Konsep 'melek Iptek' ini mengisyaraktkan agar anak-anak yang hidup saat ini dan akan mewarnai pembangunan bangsa kita dimasa depan. Penguasaan itu mulai dibina secara serius sejak dari lingkungan keluarga. Dengan memperkenalkan fakta dan konsep sederhana yang berkaitan dengan fenomena Iptek. Menurut Yaumi C. Achir (1992) sikap-sikap yang perlu dipersiapkan untuk menjadi manusia dalam era Iptek dimasa kini dan mendatang adalah 1) Taqwa terhadap Tuhan Yang Maha Esa. 2) Sadar Ilmu Pengetahuan, 3) Memiliki sikap kreatif dan rasa ingin tahu yang tidak pernah puas, 4) Disiplin diri, 5) memiliki hasrat berprestasi untuk menghasilkan perilaku atau produk yang berkualitas, 6) tangguh dan ulet, 7) mampu bekerja sama dan, 8) memiliki jiwa kepemimpinan.

\section{Keluarga Sebagai Salah Satu Pusat Pendidikan}

Kita mengenal tiga pusat berlangsungnya pendidikan; dalam keluarga, dalam sekolah dan dalam lingkungan masyarakat. Dari ketiga pusat pendidikan ini tidak sedikit yang berpandangan bahwa pendidikan di sekolah lebih dominan dibandingkan dengan hasil pendidikan lainnya. Tetapi tidak sedikit yang berpendapat bahwa lingkungan keluarga merupakan lingkungan pendidikan yang pertama dan utama. Sebab, pendidikan yang diperoleh anak dari anggota keluarga merupakan landasan bagi perkembangan kepribadian anak selanjutnya.

Ditinjau dari segi waktu, pelaksanaan pendidikan dalam lingkungan keluarga sesungguhnya tidak ada batasan berakhirnya, meski terkadang anggota tersebut telah lama meninggalkan atau memisahkan diri dari kelompok keluarga yang menaunginya selama ini. Dengan melalui berbagai media atau sarana mereka masih tetap berkomunikasi, bersosialisasi dan saling mempengaruhi. Dalam kehidupan keluarga hubungan peran tidak saja berubah pada titik yang demikian jekas, tetapi terus-menerus selama kehidupan keluarga itu ada.

Dari kenyataan ini, maka suasana modernisasi global sangat mungkin lebih cepat merasuk dalam perkembangan jiwa anak. Disamping anak-anak dapat dengan cepat dan mudah melihat perkembangan yang terjadi dari luar negeri, beserta dampak-dampak negatif yang diperoleh anak-anak, yang meskipun dalam kesehariannya ada dalam lingkungan keluarga. Jika hal ini tidak mendapat penangan yang dini dan serius sebagai bagian terbesar 
dari ibu-ibu yang ada dalam keluarga jelas akan menimbulkan kegoncangan, mengingat perkembangan jiwa anak-anak masih belum stabil, yang dapat dengan mudah dipengaruhi oleh keadaan sehari-hari.

Bergesernya karakteristik pola asuh dari pola asuh tradisionalotoriter ke pola asuh baru yang berciri demokratis atau bahkan liberal, akan memberi dampak khusu terhadap arah pertumbuhan dan perkembangan anak. Keraguan akibat dari perkenalan dengan pola asuh baru dapat menimbulkan inkonsistensi dan gangguan kesinambungan perkembangan anak sehingga akhirnya mereka tidak siap menghadapi dekade era sadar atau melek Iptek.

Kemiskinan keluarga, baik disegi ekonomi, pendidikan maupun budaya, perlu diakui sebagai faktor penyebab tidak berhasilnya keluarga menjalankan fungsinya sebagai pembina sumber daya manusia Iptek yang berkualitas. Maka dalam mewujudkan program sadar Iptek diperlukan pola kerja sama yang serasi antara keluarga, sekolah dan masyarakat. Tanggung jawab ketiganya perlu ditata secara serasi tanpa mengurangi efektifitas dan efisiensi fungsi kegiatan masingmasing.

Meningkatkan peran keluarga melalui proses penanaman nilai-nilai etis, yaitu memberikan pengertian tentang apa yang baik, yang perlu dilakukan dalam interaksi antara kaum laki-laki dan perempuan, juga tentang apa yang harus dihindari. Menanamkan bagaimana membina rumah tangga yang bahagia dan sejahtera, sikap dan cara yang baik untuk mengatasi masalah-masalah yang mengancam keutuhan rumah tangga serta tidak menonjolkan hakhak yuridis yang dapat mengangap suami atau istri sebagai lawan.

Untuk mendukung upaya ini, maka kepada masyarakat perlu diberi pengertian tentang kemandirian perempuan muda dalam pembangunan bangsa dengan menanamkan sikap : 1) meningkatkan ilmu dan ketrampilan perempuan agar mampu mandiri, 2) mengubah sikap dan pendirian agar tidak selalu tergantuk pada orang lain, 3) percaya pada diri sendiri, 4) mampu menentukan sikap dan dapat berdiri sendiri apabila diperlukan, 5) menyadarkan masyarakat untuk memberikan kesempatan pada anak perempuannya agar dapat menolong dirinya dan tidak selalu mengharap bantuan orang lain, 6) menempatkan perempuan sesuai dengan kodratnya agar tidak merugikan dirinya, keluarga, masyarakat dan negaranya, 7) menanamkan nilai kemandirian bagi kelompok kaum perempuan karena banyaknya kesempatan yang tersedia dalam era pembangunan dapat disesuaikan dengan bakat, 
Rosita Carolina, Perspektif Modernisasi.... Hal. 65 - 75

kemampuan dan kesempatan yang dimiliki.

\section{Strategi Mewujudkan Keluarga Sejahtera}

Permasalahan kaum perempuan tidak hanya mengenai masalah-masalah seperti uraian diatas tetapi juga menyangkut masalah kemiskinan yang telah memberikan kontribusi cukup besar dalam kehidupan berkeluarga. Dari laporan yang dikeluarkan TI.O suatu organisasi tenaga kerja internasional yang berjudul "Towards Gender Equality in the World of Work in Asia and the Pacific" Dalam laporan itu disebutkan bahwa di kawasan Asia selalu ada wajah perempuan yang lebih miskin daripada kaum laki-laki. Dan mereka juga lebih parah terimbas globalisasi. Krisis finansial telah menggeser keluarga kembali ke situasi yang penuh ketidak pastian pekerjaan yang eksploratif dan berupah rendah dalam perjuangan mereka agar keluarganya tetap dapat makan dan berpakaian.

Dalam sistem sosial di Indonesia tanggung jawab terhadap kelancaran pengahasilan pendapatan rumah tangga memang masih merupakan tanggung jawab suami. Meskipun dalam kenyataannya peranan keluarga sebagai penyumbang pendapatan tidaklah bisa dianggap sepele.
Upaya memberdayakan keluarga menjadi sangat relevan, bila ingin meningkatkan kesejahteraan keluarga, maka harus berani mengubah beliefs system mereka tentang hubungan kemitraan antara laki-laki dan perempuan. Selain konstruk biologis, konstruk sosial juga sangat berperan dalam membentuk beliefs sistem seseorang atau masyarakat.

Dalam upaya untuk memperdayakan keluarga, maka harus diusahakan untuk memperbaiki pandangan yang kurang tepat yang ada pada masyarakat (konstruk sosial), sehingga peran keluarga dapat mengetahui haknya dan menggunakannya dengan tepat. Program-program pemberdayaan keluarga bertujuan untuk meningkatkan kemampuan partisipasi keluarga baik sebagai individu serta sebagai anggota keluarga maupun sebagai anggota masyarakat, sehingga dapat mengembangkan kapasitasnya, dengan program-program untuk pemenuhan kebutuhan praktis, yaitu berupa peningkatan potensi keluarga dalam karier di berbagai bidang, sehingga mampu meningkatkan kesetaraan perempuan dan laki-laki.

Program untuk pembenahan kebutuhan praktis dalam keluarga, meliputi peningkatan pengetahuan dan ketrampilan, mendorong pertumbuhan kesadaran bagi diri akan peranan, tanggung jawab dan 
potensi yang dimilikinya dan peningkatan kesehatan, terutama kesehatan reproduksi, peningkatan bidang pendidikan. Salah satu masalah yang sangat krusial sekali adalah rendahnya kualitas sumber daya manusia yang ditunjukkan dari rendahnya tingkat pendidikan dalam rumah tangganya. Ada beberapa faktor yasng menyebabkan keterpurukan keluarga seperti :

- Faktor manusianya, yaitu peran keluarga itu sendiri, berupa rendahnya tingkat pendidikan dan ketrampilan, rendahnya tingkat kesehatan, sifat ketergantungan yang mengakibatkan kurang percaya akan kemampuannya.

- Faktor struktural kelembagaan, berupa berbagai ketentuan kelembagaan yang kurang mem berikan keleluasaan akses.

- Faktor pembudayaan, berupa berbagai gagasan sosial budaya dalam bentuk gender stereotype yang kurang menguntungkan keluarga.

Dari beberapa kasus yang ditemui dilapangan, bahwa dibalik keberhasilan dari sebagian besar para perempuan yang meniti karir, ternyata di rumah mereka mengalami berbagai permasalahan, jika potensi suami tidak setara dengan istrinya. Akibatnya istri dihadang oleh masalah tentang pergeseran fungsi dalam keluarga. Hal ini mensyaratkan pentingnya pendekatan interdisipliner, yang menyeluruh dan terpadu dalam menangani masalah pemberdayaan keluarga. Bahkan menurut penanganan program pemberdayaan keluarga sering tumpang tindih. Agaknya konsep Pembangunan Keluarga Sejahtera yang berbasis pada pemberdayaan keluarga dalam berbagai bidang kesehatan reproduksi, KB, ekonomi keluarga dan sebagainya merupakan wadah yang tepat dan mampu menciptakan seluruh anggota keluarga maju, berwawasan dan mandiri.

\section{PENUTUP}

Peran Keluarga ditinjau dari segi politik dan idiologi, maka peran ibu atau istri di dalam rumah tangganya sangat lah mendominasi dan dianggap penting setelah peran ayah atau suami sebagai kepala keluarga. Di dalam keluarga peran ibu selayaknya mampu membaca tanda-tanda zaman di dalam mempersiapkan generasi penerus bangsa. Disini tampak perlunya motivasi pengabdian yang kuat untuk sadar melaksanakan perannya membawa generasi penerus ke dalam kehidupan yang lebih baik.

Ada dua peran keluarga dalam pemantapan budaya Iptek, yaitu sebagai pelaku perubahan dan agen perubahan. Sebagai pelaku perubahan, perempuan harus menguasai ilmu dan teknologi (IPTEK) dan berusaha memiliki 
kepribadian yang unggul seperti pantang menyerah, kreatif, berdisiplin tinggi, bertanggung jawab, dapat dipercaya dan menjadi pendidik sentaral dan utama dalam keluarga.

Manfaat berikutnya adalah
agar kelompok ini mampu
memanfaatkan informasi tentang
Iptek dan cara penerapannya dalam
kehidupan, sehingga kelompok
perempuan muda yang ada
dipedesaan mampu memperbaiki
kehidupannya secara mandiri menuju
dan mampu menjadi ibu yang
profesional.

Partisipasi ini tidak harus selalu berwujud dengan bekerja, dalam arti mengabdikan diri pada lembaga-lembaga pendidikan, pemerintah, perusahaan maupun sejenisnya. Tetapi, lebih dari itu adalah berkerja dalam arti melaksanakan kewajibannya sebagai perempuan dalam rumah tangganya. Pemikiran ini merupakan suatu hal yang patut untuk dikaji sebelum melangkah lebih jauh, penting direnungkan karena keluarga mempunyai fungsi sendiri-sendiri dalam kehidupan dan mempunyai peran yang sudah diatur menurut kodratnya.

Keberhasilan maupun kegagalan keluarga dalam membina rumah tangganya melalui peran gandanya, dapat mewarnai bentuk dan nilai kepribadian bangsa. Atau dengan kata lain pembentukan bangsa sangat ditentukan oleh kadar profesionalisme calon ibu atau istri dalam menanamkan nilai-nilai pribadi yang harus dimiliki. Tugas ganda yang serasi dan selaras itu senantiasa menantang agar selalu dapat berpikir, merasa, bertindak selaras dan serasi sesuai dengan tuntutan harkat dan martabatnya bijaksana.

Mengembangkan kemampuan agar lebih berperan dalam pertemuan dan pergaulan sesamanya dalam dunia yang semakin transparan ini.

\section{DAFTAR PUSTAKA}

Barnadib, Imam. 1990, Perspektif Sosial Guru di Abad 21. Sajian Seminar Semarang.

Goode, William J. (alih Bahasa Lailahanoum Hasyim). 1985 Sosiologi Keluarga. Bina Aksara. Jakarta.

Imran, Indiah. 1992. Pendidikan Dalam Keluarga dan sekolah Untuk Memasuki Kehidupan Abad 21, Makalah Utama Pada Konvensi Nasional Pendidikan Indonesia II, Medan 4-8 Februari.

Semiawan, Cony. 1990. Profesionalisme Jabatan Guru. Seminar. Semarang. 
Soekanto, Soerjono. 1992. Sosiologi Suatu Pengantar. Jakarta CV. Rajawali.

Sudarmono, Pratiwi. 1992. mengoptimasi Kodrat wanita Sebagai Seorang Ibu. Harian Suara Pembaharuan 21 April 1992.

Toffer and Heidi Toffer. 1991. Power Shift. Dialih bahasakan oleh Hermawan Sulitia, Jakarta: panca Simpati

Vitalaya, H. Aida. 1992. Perempuan Dulu, Kini dan Nanti. Harian Pelita, 8 Maret . Jakarta.

Zubaidah. M. 1990. Motivasi Peningkatan Peranan Wanita, Proyek Peningkatan Peranan Wanita Jakarta.

Naisbitt, John and Patricia Aburdence. 1990. Megatrends 2000. Dialih bahasakan oleh FX Budiyanto. Binarupa Aksara. Jakarta. 